\title{
Analysis of environmental risks and accidents at work in urban solid waste collection services
}

\author{
Análise dos riscos ambientais e de acidentes de trabalho em \\ serviços de coleta de resíduos sólidos urbanos \\ Caroline Cipolatto Ferrão ${ }^{1}$ (D), Jorge André Ribas Moraes ${ }^{1}$ \\ 1Universidade de Santa Cruz do Sul - UNISC, Santa Cruz do Sul, RS, Brasil. E-mail: carolinecipolatto@gmail.com \\ jorge@unisc.br
}

How to cite: Ferrão, C. C., \& Moraes, J. A. R. (2021). Analysis of environmental risks and accidents at work in urban solid waste collection services. Gestão \& Produção, 28(1), e4885.

https://doi.org/10.1590/1806-9649.2020v28e4885

\begin{abstract}
The heterogeneity and the volume of solid urban waste generated daily cause difficulties in their management, which causes environmental impacts, health and public safety problems. Among all waste management activities, collection is one of the most relevant from an occupational point of view because employees are subject to physical, chemical, biological, ergonomic risks as well as suffering accident. This article aims to instruct companies to apply multidisciplinary management tools that conciliate and serve as a basis for decision making related to environmental and occupational safety management. Therefore, the Ad Hoc Environmental Impact Assessment techniques and the RMT Risk Management Tool were used to identify the environmental impacts generated and the risks to which employees in the urban solid waste collection sector are exposed. It happened through the collection of operational, environmental information and work safety data, in 2017, of companies operating in 7 (seven) municipalities in the state of Rio Grande do Sul. The Ad Hoc report showed that the environmental aspects of surface water, groundwater, soil, odor and air pollution, generate negative and irreversible environmental impacts. Furthermore, the analysis of accidents at work, the identification of the major agents that cause accidents at work and the nature of injuries, showed their high frequency and severity. In total 60 accidents were recorded and all occurred with garbage collectors. Among these, 13 had as causative agents "glassware, fiberglass, blade, except vial, bottle" and the most recurrent types of injuries were "excoriation and abrasion (superficial wound)" and "by cutting, laceration, blunt wound, puncture (open wound)", both with $22 \%$ of occurrence, which generate work leave. Furthermore, the elaboration of Action Plans and application of the $5 \mathrm{~W} 2 \mathrm{H}$ Quality Management tool proved to be excellent tools for assessments regarding the minimization of environmental impacts and the control of accidents at work.
\end{abstract}

Keywords: Urban solid waste; Occupational safety; Occupational accidents; Environmental impacts; Risk management; Quality Management.

Resumo: A heterogeneidade e o volume de resíduos sólidos urbanos gerados diariamente causam dificuldades no gerenciamento dos mesmos, o que ocasiona impactos ambientais, problemas de saúde e de segurança pública. Entre todas as atividades de gestão de resíduos, a coleta é uma das mais relevantes do ponto de vista ocupacional devido aos colaboradores estarem sujeitos a riscos físicos, químicos, biológicos, ergonômicos e de acidentes. Este artigo

Received Dec. 4, 2018 - Accepted June 14, 2020

Financial support: None.

This is an Open Access article distributed under the terms of the Creative Commons Attribution License, which permits unrestricted use, distribution, and reproduction in any medium, provided the original work is properly cited. 
tem como objetivo instruir empresas a aplicarem ferramentas de gestão multidisciplinares que conciliem e sirvam de base para as tomadas de decisão relacionadas com a gestão operacional ambiental e de segurança do trabalho. Sendo assim, foram utilizadas as técnicas de Avaliação de Impactos Ambientais Ad Hoc e a ferramenta de Gestão de Risco APR para a identificação dos impactos ambientais gerados e dos riscos aos quais os colaboradores do ramo de coleta de resíduos sólidos urbanos são expostos, através da coleta de informações operacionais, ambientais e dados de segurança do trabalho, no ano de 2017, de empresas que atuam em 7 (sete) municípios do estado do Rio Grande do Sul. O relatório Ad Hoc mostrou que os aspectos ambientais águas superficiais, águas subterrâneas, solo, odor e poluição do ar, geram impactos ambientais negativos e irreversíveis. Para mais, a análise dos acidentes de trabalho, a identificação dos maiores agentes causadores dos acidentes de trabalho e da natureza das lesões, mostraram a alta frequência e gravidade dos mesmos. No total foram contabilizados 60 acidentes e todos ocorreram com coletores de lixo. Destes, 13 tiveram como agentes causadores "vidraria, fibra de vidro, lâmina, exceto frasco, garrafa" e as naturezas de lesões mais recorrentes foram por "escoriação e abrasão (ferimento superficial)" e "por corte, laceração, ferida contusa, punctura (ferida aberta)", ambas com $22 \%$ de ocorrência, os quais geram afastamento do trabalho. Para mais, a elaboração de Planos de Ação e aplicação da ferramenta de Gestão de Qualidade 5W2H mostraram-se ótimas ferramentas para as avaliações referentes a minimização dos impactos ambientais e ao controle dos acidentes de trabalho.

Palavras-chave: Resíduos sólidos urbanos; Segurança do trabalho; Acidentes de trabalho; Impactos ambientais; Gestão de risco; Gestão de Qualidade.

\section{Introduction}

The pace of population, industrial and economic growth directly influences the search for a better quality of life and, consequently, the volume of waste generated. Management Solid Waste (MSW) is the most heterogeneous type of waste, resulting from the multiplicity of activities in urban environments. Thus, their inadequate management causes negative environmental impacts (air, soil and water pollution), in addition to health problems (diseases related to insects, rodents and different forms of pollution) and public safety (Ripa et al., 2017; Erses Yay, 2015).

Considering this situation, Law 12,305 of 2010 (Brasil, 2010), which advocates the National Solid Waste Policy (NSWP), gathers a set of principles, objectives, instruments, guidelines, goals and actions to be taken considering an integrated management and adequate solid waste management. Thus, the NSWP is an extremely important tool to guide public managers, the population and companies, so that the best alternatives are applied to minimize the environmental impacts generated by the inadequate management of the waste generated.

In this context and following the NSWP approach, municipalities have a responsibility to manage the MSW generated by society. Therefore, it is the public managers' responsibility to choose the type of collection (conventional, conventional and selective, conventional with waste separation in dry / wet or still containerized), transportation, appropriate final destination. These services might be offered by the municipality itself or by hiring companies through public bidding.

Among the different activities involved in the management of urban waste, the collection is one of the most relevant, both for the cost and for the potential impacts on the quality of the urban context (Di Maria et al., 2016). This activity requires care in the administration of the best alternatives from the environmental point of view as well as in terms of work safety, since the employees involved with it are subject to physical, chemical, biological, ergonomic and accident risks. The risks involved in the activity 
may compromise the performance of the work teams, as they will be absent due to leave caused by work accidents.

In this way, the importance of workers in this area, since the activity of collecting solid urban waste is an activity considered essential in all municipalities and, therefore, risk management in this service is necessary.

For the collection of household solid urban waste, the number of existing employees in each municipality and the size of the fleet required to perform the services depend on factors such as the size of the municipality, number of inhabitants, waste generation, local economic activities, among others. Therefore, this dimensioning, which is essential, must be done by trained people, fulfilled by the hired company and properly supervised.

Therefore, this article aims to instruct companies to apply multidisciplinary management tools that conciliate and serve as a basis for decision making related to environmental and occupational safety management. To this end, the field of urban solid waste collection was chosen and the Ad Hoc Environmental Impact Assessment techniques and the RMT Risk Management tool were applied to identify the environmental impacts generated and the risks to which employees were exposed, respectively. Finally, Action Plans were drawn up and the 5W2H Quality Management tool was used to provide options for minimizing environmental impacts and greater control of occupational accidents.

\section{Literature review}

The recognition of the effects, generally negative, caused to the environment through anthropic activities, such as the generation of waste, led to the creation of basic rules and conditions so that an activity can appropriate an area in a given space, aiming not to cause significant changes to the environment. In this context, Environmental Impact Assessment (EIA) methods were formulated, which for excellence are dedicated to making predictions of the effects of a specific activity in the short, medium and long term (Cremonez et al., 2014).

Among the main techniques for assessing environmental impacts are the Checklist, the Card Overlay, the Baterle Method, the Leopold Matrix, the Ad Hoc methodology, among others. The safe choice of the methodology to be applied allows obtaining a more accurate and reliable assessment aimed at mitigating negative impacts on the environment (Cremonez et al., 2014).

The evaluation of environmental impacts in the waste area is academically focused, mainly on the application of structured techniques to support decision making through the assembly and simulation of scenarios or future alternatives for the collection and treatment of urban solid waste. The most used technique is Life Cycle Analysis (LCA), which seeks the best combination of technologies that result in an environmentally effective system in terms of gaseous, liquid and solid waste emissions, which is economically viable and socially acceptable by population (Reichert \& Mendes, 2014). The following can be cited as examples: Bernstad Saraiva et al. (2017), Deus et al. (2017), Herva et al. (2014) and Carra \& Reichert (2014).

All activities involving risks, whether environmental or occupational accidents, must be managed. The risk management process supports decision-making, taking into account the uncertainties and the possibility of future circumstances or events and their effects on the agreed objectives (ABNT, 2012). Therefore, the NBR ISO 31.010 standard (ABNT, 2012), entitled Risk management - Techniques for the risk 
assessment process provide guidance on the selection and application of systematic techniques for the risk assessment process at the organizational or departmental level, for individual projects, activities or specific risks.

The risk management techniques suggested by the regulation 31.010 (ABNT, 2012) include the application of logical and systematic methods, which may require a multidisciplinary approach due to the large number of possible causes and consequences. Some of the tools mentioned in the regulations are: checklists, Preliminary Risk Analysis (RMT) or Preliminary Hazard Analysis (PHA), Hazards and Operability Study (HAZOP), Hazard Analysis and Critical Control Points (HACCP), Structured Technique "What if" (SWIFT), Failure Mode and Effect Analysis (FMEA), Failure Tree Analysis (FTA), Cause and Consequence / Effect Analysis, and others. Among the benefits of applying these tools, it is necessary to understand the risk and its potential impact on the objectives; provide information to decision makers; communicate risks and uncertainties; assist in setting priorities; following regulatory requirements (ABNT, 2012).

According to Da Silva et al. (2017), through the use of risk management methodologies it is possible to achieve the objective of preventing accidents in addition to reducing costs involved in the work environment. Regardless the method, it is necessary to follow a sequence in the work environment to be studied, such as the identification of hazards and identification of consequences based on the recognition of hazards.

Directed to the area of household solid waste collection, Silva et al. (2016) analyzed the possible occupational risks of workers who work in the collection from a bibliographic research and a case study with the application of a questionnaire. The greatest risks described in the study were inadequate packaging of broken glass, bruises / sprains and falls from the transport vehicle.

Among the other risks, the bad smell of the waste was emphasized, which promotes the abandonment by the employees who are looking for a job; contact with sharp objects; the noises from the truck itself and traffic; the fact that the bags with waste are torn by animals or by scavengers and; exposure to chemical and biological agents, where the use of masks and gloves reduces the chances of acquiring some type of occupational disease. Another pertinent issue was regarding exposure to rain, cold and heat and, consequently, body pain and exhaustion at the end of the working day. The suggestion aimed at relieving the sensation of pain or discomfort in the body / muscles after the workday was to perform labor gymnastics (Silva et al., 2016).

de Jesus Galdino \& Malysz (2016) proposed to identify and diagnose the occupational risks involved in waste collectors in the municipality of Mamborê - PR. The factors that most contribute to work accidents are the difficulties in the use of Personal Protective Equipment (PPE), the fast pace of work and the neglect of residents regarding the disposal of waste for collection. The main consequences observed were: cuts, injuries, falls, constant exposure to biological and physical agents and ergonomic problems.

Other issues pointed out were the exposure to vibrations due to displacements in the stirrup of the compactor truck in different areas of the urban perimeter; and the responsibility that employees must have for safety in making individual and collective decisions in order to keep up with the pace of work and the truck (by de Jesus Galdino \& Malysz, 2016).

de Jesus Galdino \& Malysz (2016) pointed out that the time factor is very present in the routine of those who work with the collection of solid urban waste, since there are 
predetermined times for the fulfillment of activities in each sector (unification of some neighborhoods). This factor influences the pace of work, the organization of the teams and the quality of the service provided. In addition to varying according to the infrastructure of the roads, the characteristics of the vehicles made available and the way in which the waste is stored by the community.

Silva et al. (2016) and de Jesus Galdino \& Malysz (2016) emphasized the neglect of the population in face of the separation of waste in their own homes. When done incorrectly, the disposal of waste on public roads makes it difficult for those who collect it, slowing down the pace of the teams and causing exposure to the risk of injury from sharps and contaminated materials.

According to Aleluia \& Ferrão (2016), the separation of waste at the source, or else, in homes, is a participatory measure that requires cooperation from those who generate the waste, whether individuals, families or commercial or industrial establishments. In addition to causing significant changes in the quality and quantity of the collected waste, the increase in the rate of separation of waste mainly causes a reduction in the risks to which workers are subjected during the working day (Struk, 2017; Sukholthaman \& Sharp, 2016).

The regulation NBR 14.280 (ABNT, 2001) provides for the Work Accident Register - Procedures and Classification and sets criteria for the registration, communication, statistics, investigation and analysis of work accidents, their causes and consequences, applying to any labor activities. Therefore, the work accident is an unpredictable and undesirable occurrence, instantaneous or not, related to the exercise of the work, which results or may result in personal injury (ABNT, 2001).

This regulation aims to identify and record fundamental events related to accidents at work without, however, indicating specific corrective measures, or referring to failures or means of correcting the conditions or circumstances that culminate in the accident (ABNT, 2001).

Comberti et al. (2018) state that the investigation of occupational accidents is fundamental for risk management. The basis for this is that the process of reporting and collecting occurrences of accidents in an organized database supports companies in planning risk investigation procedures, aiming to correct existing situations and avoid new similar incidents.

The Brazilian government holds the Ministry of Finance website (DATAPREV, 2016) which offers access to a database (AEAT InfoLogo $($ ) with statistics on accidents at work with data from 1999 to 2016. This historical database is fed by the Secretariat of Social Security. Table 1 comes from AEAT InfoLogo ${ }^{\circledR}$ and presents data from Brazil and the state of Rio Grande do Sul referring to work accidents with the National Classification of Economic Activity 3.811: Collection of Non-Hazardous Waste and Group National Classification of Economic Activity: Collection, Treatment and Disposal of Waste - Material Recovery.

Table 1. Historical data on occupational accidents in Brazil and in the state of Rio Grande do Sul for National Classification of Economic Activity 3,811: Collection of Non-Hazardous Waste.

\begin{tabular}{llcccccc}
\hline \multicolumn{1}{c}{ BRAZIL } & & & & & & & \\
\hline Reason/Situation & $\mathbf{2 0 1 1}$ & $\mathbf{2 0 1 2}$ & $\mathbf{2 0 1 3}$ & $\mathbf{2 0 1 4}$ & $\mathbf{2 0 1 5}$ & $\mathbf{2 0 1 6}$ & Total \\
\hline Typical - with Communication of Work Accidents (CWA) & 5.170 & 5.500 & 5.551 & 5.519 & 5.360 & 5.216 & 32.316 \\
\hline Route - with CWA & 659 & 678 & 733 & 708 & 655 & 629 & 4.062 \\
\hline Occupational Disease - with CWA & 45 & 53 & 60 & 54 & 101 & 44 & 357 \\
\hline Without CWA & 1.010 & 930 & 845 & 0 & 269 & 279 & 3.333 \\
\hline Total & 6.884 & 7.161 & 7.189 & 6.281 & 6.385 & 6.168 & 40.068 \\
\hline
\end{tabular}


Table 1. Continued...

\begin{tabular}{|c|c|c|c|c|c|c|c|}
\hline \multicolumn{8}{|c|}{ BRAZIL } \\
\hline RIO GRANDE DO SUL & & & & & & & \\
\hline Motivo/Situação & 2011 & 2012 & 2013 & 2014 & 2015 & 2016 & Total \\
\hline Typical - with CWA & 329 & 355 & 296 & 363 & 397 & 318 & 2.058 \\
\hline Route - with CWA & 25 & 28 & 35 & 25 & 33 & 22 & 168 \\
\hline Occupational Disease - with CWA & 3 & 4 & 1 & 2 & 1 & 5 & 16 \\
\hline Without CWA & 40 & 46 & 38 & 0 & 10 & 13 & 147 \\
\hline Total & 397 & 433 & 370 & 390 & 441 & 358 & 2.389 \\
\hline
\end{tabular}

Source: DATAPREV (2018).

As it shown on Table 1 does not show a growth or a trend in relation to the records of occupational accidents over the years. Moreover, typical accidents with CWA registration represent $80.65 \%$ and $86.14 \%$ of the total in Brazil and Rio Grande do Sul respectively. The total record in Rio Grande de Sul is equivalent to $5.96 \%$ of the accidents reported in the country. These numbers can be attributed to several factors such as access to information, economics, and high coverage rate of the collection of solid urban waste in south region (Rio Grande do Sul, Santa Catarina and Paraná) which, according to ABRELPE (2016) is approximately $95 \%$, among others.

In order to minimize the environmental impacts generated by the activity of collecting solid urban waste and the risks of accidents to be controlled, action plans may be developed together with the application of quality management tools.

According to NBR ISO 9.001 (ABNT, 2015), the use of a quality management system is a strategic decision for a company, which helps to improve its global development and promotes sustainable development. Nunhes et al. (2017) highlights some quality management tools such as 5W2H, Brainstorming, Benchmarking, SPC, FMEA, Pareto Diagram, Lean Production, Cleaner Production and others.

\section{Methodology}

The methodology of this article is divided into 7 (seven) stages, as shown in Figure 1.

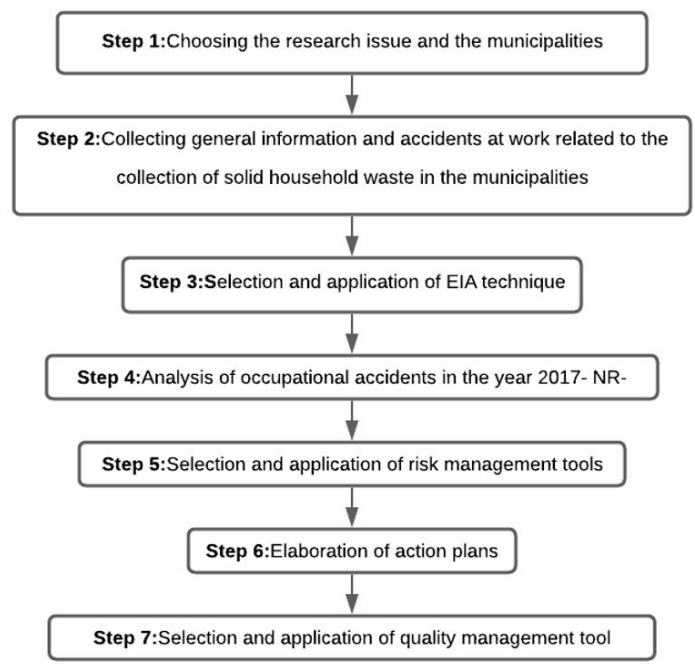

Figure 1. Flowchart of the applied methodology. 
Step 1 corresponds to the analysis of operational activities related to the collection of household solid waste and the choice of 7 (seven) municipalities in the state of Rio Grande do Sul which had the availability of waste collection companies to collaborate with data collection.

For Step 2, the companies responsible for the collection services provided information on occupational safety related to the activities performed. In one of the municipalities, the routine of the services was monitored in order to obtain an assertive diagnosis of the environmental impacts resulting from the activity in addition to situations related to work safety.

For the Evaluation of the Environmental Impacts of the waste collection activity, the Ad Hoc method was applied in Step 3. According to Stamm (2003), the Ad Hoc methodology arose from the need to make decisions about the implementation of projects and activities, considering, in addition to economic and technical reasons, the opinion of experts in each type of impact arising from the project. For the preparation of an Ad Hoc report, it is essential to form multidisciplinary working groups that have some affinity or experience with the type of project or activity to be analyzed.

This method may be developed in a short period of time and when there is a small availability of information on the resulting impacts. Stamm (2003) also states that the bibliography presents the Delphi technique as one of the best known examples of the Ad Hoc method. The Delphi technique can be applied at any step of a life cycle system or at any step of the ABNT risk management process (ABNT, 2012).

Setting the condition, the chosen environmental aspects result in direct or indirect environmental impacts, which can be noticed throughout the household waste collection services. The environmental aspects selected were: surface water, groundwater, soil, fauna and flora, noise, odor, air pollution, public infrastructure, socioeconomic aspects and compatibility with municipal plans. Subsequently, the environmental aspects had their respective environmental impacts classified by a multidisciplinary group of researchers in the area as: "without effect", "positive effect", "negative effect", "beneficial", "adverse", "problematic", " short term", "long term", " reversible " and "irreversible ".

As background for Step 4, concerning the analysis of accidents at work, the Regulatory Standard NR-4 - Specialized Services in Safety Engineering and Occupational Medicine - SESMT (Brasil, 2016) was used. It imposes the analysis and record in a specific document(s) of all accidents occurring in the company or establishment, with or without a victim, and of all cases of occupational disease, describing the history and characteristics of the accident and/or occupational disease, environmental factors, the characteristics of the agent and the conditions of the individual(s) with an occupational or accident illness (es).

This regulation also requires the register of monthly updated data on occupational accidents, occupational diseases and unhealthy agents. For this reason, the minimum requirements described in models available in the standard itself must be fulfilled, and the employer must leave the documentation at the disposal of labor inspections (Brasil, 2016). In this context, the complementarity of NR-4 with NBR 14,280 (Work Accident Register) (ABNT, 2001) is perceived in risk management issues.

Thus, the records of companies from 7 (seven) municipalities were used to carry out the survey of the number of workers; the functions performed, the man-hours worked, the number of accidents that occurred throughout the year with reports of accidents at work (CWA) with and without injury, throughout 2017. This study covered the employees of the following functions: urban waste collectors, drivers, operational managers and administrative assistants. The analysis of accidents at work also served to obtain the causative agents and the nature of injuries at work.

Through the survey of CWAs, the obtained data were inserted into an Excel spreadsheet, similar to those presented by NR-4 (Brasil, 2016) and the calculations of 
hour of exposure to the risk of accidents, accident frequency rate, rate frequency of accident victims with injury with leave, frequency rate of accident victims with injury without leave and severity rate, according to NBR 14.280 (ABNT, 2001). All of these variables are related to a predetermined period for the analysis.

The man-hour of exposure to accident risk $(\mathrm{H})$ was calculated from the sum of the hours which employees are available to the employer. The accident frequency rate (Tx Freq) corresponded to the number of accidents $(\mathrm{N})$ per million man-hours of risk exposure, as described in formula 1 :

TxFreq $=\frac{N \cdot 1.000 .000}{H}$

The frequency rate of accident victims with injury with leave (Freq Rate Lca) was given by the number of accident victims with injury with leave (Nca) per million manhours of risk exposure, according to the following formula 2 :

TxFreq $L c a=\frac{N c a \cdot 1.000 .000}{H}$

In the same way, the frequency rate of accidents with injuries without leave was found (Freq Rate Lsa). The severity rate $(G)$ was consistent with the computed time (T) per million man-hours of risk exposure, according to the following formula 3 :

$G=\frac{T \cdot 1.000 .000}{H}$

In addition, the relative rate of accidents at work (ARI) was also calculated, which related the number of accidents $(\mathrm{N})$ to the total number of workers $(\mathrm{Nt})$, detailed in formula 4 :

$A R I=\frac{N}{N t} \cdot 100$

For Step 5, the RMT Risk Management Tool was selected and applied, using the methodology of De Cicco \& Fantazzini (2003) and following Faria's guidelines (2011). RMT is a simple and inductive analysis technique that aims to identify the risks which can cause damage in a particular activity, installation or system. It is most commonly used at the beginning of the development of a project or operational procedure, but the RMT is also useful when analyzing existing systems to prioritize hazards and risks or when circumstances prevent the use of a more extensive technique (ABNT, 2012).

This technique has as its positive points the ability to be used with little information and the early consideration of risks to the system's life cycle. However, it is emphasized that the qualitative analysis of the consequences of an undesirable event and its probabilities help to identify the risks for further evaluation (ABNT, 2012).

In RMT, the risk index is given by multiplying the adopted weights of severity and frequency according to the list of causes and consequences. The degrees of severity and frequency are shown in Tables 2 and 3 respectively, and the risk index in Table 4. 
Table 2. Severity level of accidents.

\begin{tabular}{ccll}
\hline & & \multicolumn{2}{c}{ Severity } \\
\hline Degree & Effect & Description & Clearance \\
\hline 1 & Mild & Accidents that do not cause injuries & $\begin{array}{l}\text { Without } \\
\text { Leave }\end{array}$ \\
\hline 2 & Moderate & Accidents with leave and non-incapacitating injuries & $\begin{array}{l}\text { From } 1 \text { to } \\
30 \text { days }\end{array}$ \\
\hline 3 & Major & $\begin{array}{l}\text { Accidents with leave and incapacitating injuries, } \\
\text { without loss of substances or limbs }\end{array}$ & $\begin{array}{l}\text { From } 31 \text { to } \\
60 \text { days }\end{array}$ \\
\hline 4 & Severe & $\begin{array}{l}\text { Accidents with leave and incapacitating injuries, } \\
\text { with loss of substances or limbs }\end{array}$ & $\begin{array}{l}\text { From } 61 \text { to } \\
90 \text { days }\end{array}$ \\
\hline 5 & Catastrophic & Death or permanent disability & No return \\
\hline
\end{tabular}

Source: adapted from Faria (2011).

Table 3. Frequency or probability of accidents.

\begin{tabular}{ccll}
\hline \multicolumn{4}{c}{ Frequency or Probability } \\
\hline Degree & Ocorrence & Description & Frequency \\
\hline 1 & Improbable & Very low probability of damage occurring & Once every 02 years \\
\hline 2 & Possible & Low probability of damage occurring & Once every 01 year \\
\hline 3 & Occasional & Moderate likelihood of damage occurring & Once every semester \\
\hline 4 & Regular & High probability of damage occurring & Once every 3 months \\
\hline 5 & Right & Very high probability of damage occurring & At least once a month \\
\hline
\end{tabular}

Source: adapted from Faria (2011).

Table 4. Risk index and action management.

\begin{tabular}{ccl}
\hline Risk Idex & $\begin{array}{c}\text { Type of } \\
\text { risk }\end{array}$ & Level of actions \\
\hline Up to 3 & Trivial & $\begin{array}{l}\text { Do not require special actions, neither preventive nor } \\
\text { detection }\end{array}$ \\
\hline From 4 to 6 & Tolerable & $\begin{array}{l}\text { Do not require immediate action. They may be } \\
\text { implemented in due time, depending on the availability of } \\
\text { labor and financial resources }\end{array}$ \\
\hline From 8 to 10 & Moderate & $\begin{array}{l}\text { Requires prevision and definition of deadline and } \\
\text { responsibility for the implementation of actions }\end{array}$ \\
\hline From 12 to 20 & Relevant & $\begin{array}{l}\text { Requires immediate implementation of actions and } \\
\text { definition of responsibilities. Work can be released for } \\
\text { execution only with follow-up and continuous monitoring. } \\
\text { The interruption of work can happen when conditions } \\
\text { present some lack of control }\end{array}$ \\
\hline Greater than 20 & Intolerable & $\begin{array}{l}\text { The works cannot be started and if they are in } \\
\text { progress, they must be stopped immediately and can } \\
\text { only be restarted after implementing corrective } \\
\text { actions }\end{array}$ \\
\hline
\end{tabular}

Source: adapted from Faria (2011).

The following may be cited as limitations of the RMT: the failure to provide detailed information about the risks and forms of prevention, the fact that it is not a comprehensive technique and for providing only preliminary information (ABNT, 2012). Because of this, 
the RMT and the information in the Ad Hoc report were used to prepare an Action Plan (Step 6) that gathered and linked the environmental impacts and the types of risk of occupational accidents obtained by the risk indices generated.

In order to structure the action plans obtained, in Step 7, the Quality Management tool $5 \mathrm{~W} 2 \mathrm{H}$ (what, when, where, who, why, how, how much) was applied. Therefore, for each problem identified, analyzed and prioritized, it is necessary to develop a specific action plan to solve it (Nunhes et al., 2017). For this, the following questions were asked and answered: "what to do?", "When to do it", "who is going to do it", "why do it?", "Where to do it", "how to do it?" and "how much will it cost?."

\section{Results and discussion}

The collection of household solid waste has direct or indirect environmental impacts, that means that it might be noticed during the services or not. Thus, the environmental aspects raised with the use of the Ad Hoc Environmental Impact Assessment technique were surface water, groundwater, soil, fauna and flora, noise, air pollution, use of natural resources, human health (infrastructure), aspects and compatibility with municipal plans. Table 5 details the classifications of environmental aspects according to the respective environmental impacts generated.

Table 5. Ad Hoc report on environmental impacts.

\begin{tabular}{|c|c|c|c|c|c|c|c|c|c|c|}
\hline \multirow{2}{*}{$\begin{array}{c}\text { Environmental } \\
\text { Aspects } \\
\text { Ambientais }\end{array}$} & \multicolumn{10}{|c|}{ ENVIRONMENTAL IMPACTS } \\
\hline & NE & PE & NE & B & $A$ & $P$ & ST & LT & $\mathbf{R}$ & I \\
\hline Surface water & & & $\mathrm{X}$ & & & $x$ & & $X$ & & $\mathrm{X}$ \\
\hline Groundwater & & & $\mathrm{X}$ & & & $x$ & & $\mathrm{X}$ & & $\mathrm{X}$ \\
\hline Soil & & & $\mathrm{X}$ & & & $x$ & & $X$ & & $\mathrm{X}$ \\
\hline Fauna and flora & & & $\mathrm{X}$ & & & $x$ & & $\mathrm{X}$ & & $\mathrm{X}$ \\
\hline Noise & & & $\mathrm{X}$ & & & $x$ & $\mathrm{x}$ & & $X$ & \\
\hline Odor & & & $\mathrm{X}$ & & $x$ & & $\mathrm{x}$ & & & $\mathrm{X}$ \\
\hline Air pollution & & & $x$ & & & $x$ & & $X$ & & $\mathrm{x}$ \\
\hline $\begin{array}{l}\text { Public } \\
\text { infrastructure }\end{array}$ & & $x$ & & $\mathrm{X}$ & & & & $\mathrm{X}$ & $\mathrm{X}$ & \\
\hline $\begin{array}{l}\text { Socioeconomic } \\
\text { aspects }\end{array}$ & & $x$ & & $x$ & & & & $\mathrm{X}$ & $\mathrm{X}$ & \\
\hline $\begin{array}{l}\text { Compatibility with } \\
\text { municipal plans }\end{array}$ & & $x$ & & $x$ & & & & $\mathrm{X}$ & $\mathrm{X}$ & \\
\hline
\end{tabular}

Note: $\mathrm{NE}=$ no effect; $\mathrm{PE}=$ positive effect; $\mathrm{NE}=$ negative effect; $\mathrm{B}=$ beneficial; $\mathrm{A}=$ adverse; $\mathrm{P}=$ problematic; $\mathrm{ST}=$ short term; $\mathrm{LT}=$ long term; $\mathrm{R}=$ reversible; $\mathrm{I}$ = irreversible.

For environmental aspects, surface water, groundwater, soil and fauna and flora; environmental impacts resulting from poor packaging and inadequate disposal for the collection of waste on public roads, streets or land were considered. These practices expose waste to bad weather, which accelerates the decomposition of organic waste and the production of leachate, which, in the absence of a suitable place, negatively influence all the environmental aspects mentioned above. Thus, its impacts were classified as having a negative, problematic effect, with long-term and irreversible consequences.

Noise and odor directly affect workers linked to the collection activity, as well as the population. However, the period that directly affects the population at a certain point, 
depends on the sectorization of the municipality and the frequency of collection. What differentiated them in the classification of impacts was that the noise was considered problematic because wherever the truck passes, there will be this annoyance. However, it can be reversible, through the correct maintenance of vehicles. The odor was considered an adverse impact, due to the periodicity of the collection, which must have a schedule that avoids the disposal of this residue outdoors for a long time. However, its impact was considered irreversible, due to not being able to prevent its decomposition.

Air pollution is linked to atmospheric emissions from the consumption of fossil fuels used by trucks in services. Therefore, it was considered to have an environmental aspect that causes impacts with a negative, problematic, long-term and irreversible effect.

The item of public infrastructure takes into account the importance of this type of service, since basic sanitation directly interferes with the proliferation of diseases. The economic aspects are linked to the generation of jobs in the industry. In addition, compatibility with municipal plans includes compliance with current legislation that must be obeyed. Therefore, these three environmental aspects were considered as impacts with positive, beneficial, long-term and reversible effects, as they can always be improved or changed with each new public management.

The analysis of occupational accidents that occurred throughout 2017, in the 7 chosen municipalities of the state of Rio Grande do Sul, is presented in Table 6. Accidents that occurred with the following functions were considered: administrative assistant, operational manager, drivers and urban waste collectors. I

In total, 60 occupational accidents were recorded, according to column 8, with the observation that all occurred with urban waste collectors. The vast majority of accidents with injuries were absent, 51 of the cases, according to column 7; and the average was approximately 11 days lost by accident. Thus, it is clear that accidents that occur in this line of activity generate serious injuries that keep employees away from their work fronts, reducing employees by teams and overloading those who continue in a matter of effort.

For every million man-hours of risk exposure, an average of 174.93 accidents occur, as can be seen from the average accident frequency rate, represented by column 10 . The average percentage of employees who suffered occupational accidents in 2017 in seven municipalities was $37.50 \%$, as can be seen in column 14 . This percentage reveals how likely to occupational accidents workers in the industry are exposed to.

Table 6. Analysis of occupational accidents that occurred in 2017 in seven municipalities in the state of Rio Grande do Sul.

\begin{tabular}{ccccccccccccc}
\hline Year Municipalities & TN & H & T & Lsa Lca & $\begin{array}{c}\text { Notal } \\
\text { days } \\
\text { lost }\end{array}$ & $\begin{array}{c}\text { Freq } \\
\text { Rate }\end{array}$ & $\begin{array}{c}\text { Freq } \\
\text { Rate } \\
\text { Lsa }\end{array}$ & $\begin{array}{c}\text { Freq } \\
\text { Rate } \\
\text { Lca }\end{array}$ & G & RIA \\
\hline M1 & 30 & $74.631,86$ & $249 / 301$ & 0 & 8 & 8 & 225 & 107,19 & 0 & 107,19 & 301,48 & $26,67 \%$ \\
\hline M2 & 17 & $42.023,53$ & $249 / 301$ & 0 & 4 & 4 & 23 & 95,18 & 0 & 95,18 & 54,73 & $23,53 \%$ \\
\hline M3 & 46 & $101.488,93$ & $249 / 301$ & 2 & 5 & 7 & 126 & 68,97 & 19,71 & 49,27 & 124,15 & $15,22 \%$ \\
\hline M4 & 14 & $34.498,53$ & $249 / 301$ & 0 & 10 & 10 & 42 & 289,87 & 0 & 289,87 & 121,74 & $71,43 \%$ \\
\hline M5 & 38 & $73.829,20$ & $249 / 301$ & 2 & 7 & 9 & 49 & 121,90 & 27,09 & 94,81 & 66,37 & $23,68 \%$ \\
\hline M6 & 20 & $38.119,33$ & $249 / 301$ & 5 & 9 & 14 & 31 & 367,27 & 131,17 & 236,10 & 81,32 & $70,00 \%$ \\
\hline M7 & 25 & $45.936,53$ & $249 / 301$ & 0 & 8 & 8 & 59 & 174,15 & 0 & 174,15 & 128,44 & $32,00 \%$ \\
\hline
\end{tabular}

Note: $\mathrm{M} 1$ to $\mathrm{M} 7$ = municipalities; $\mathrm{TN}=$ total number of workers; $\mathrm{H}=$ man-hours worked; $\mathrm{T}=$ computed time; $\mathrm{Lsa}=$ number of accidents without lost time; $\mathrm{Lca}=$ number of accidents with leave; $\mathrm{N}=$ total number of accidents; Freq Rate $=$ frequency rate; Freq Rate $L s a=$ frequency rate of accident victims with injury with leave; Freq Rate Lca = frequency rate of accident victims with injury without leave; $\mathrm{G}=$ severity rate; RIA = relative index of accidents at work. 
Figure 2 shows all the agents that caused accidents at work during 2017 in the seven municipalities studied. Accidents caused by "glassware, fiberglass, blade, except vial, bottle" were the most frequent, totaling 13 events. These data prove the population's lack of care when packaging and disposing of sharp residuals on the public road, corroborating what was presented in the study by Silva et al. (2016). Many accidents could be avoided with a simple signal so that the collectors would be careful when handling the casings.

Subsequently, "street and road - surface used to support people" appear with 10 occurrences; "Scaffolding floor and demountable platform - surface used to support people" and "vehicle" with 5; "Live animal" with 4; "Infectious or parasitic agent - included bacteria, fungi, parasitic organisms, viruses, etc., not including chemical, pharmaceutical preparation or food", "motorcycle, scooter" and "living being" with 3; "Flask, bottle - packaging, container, empty or full", "support surface - surface used to support people" with 2 and the other causative agents with only 1 case.

As shown in Figure 3, for the municipalities used in the survey, the most recurrent types of injuries were "excoriation and abrasion (superficial wound)" and "cut, laceration, blunt wound, puncture (open wound)", both with $22 \%$, followed by "immediate injury", and "distension and sprain" with $13 \%$. Following, the occurrence of "crushing bruise"; "Cut, laceration, blunt wound, puncture" and; "Dislocation" appear with $12 \%, 8 \%$ and $7 \%$, respectively. The nature of the least incident injury is the "fracture" with $3 \%$.

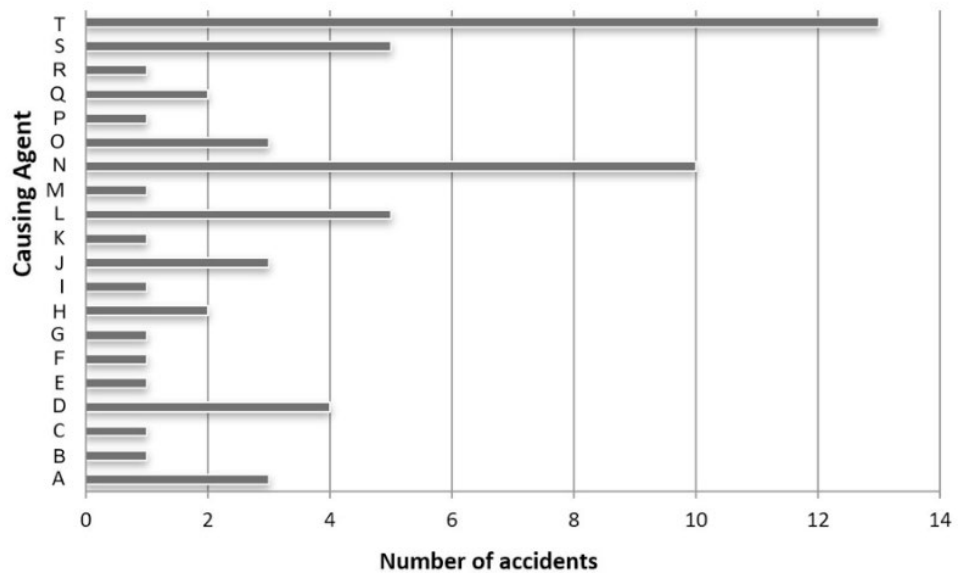

Figure 2. Agents causing accidents at work. Graphic Subtitle: The letters correspond to: A) Infectious or parasitic agent - included bacteria, fungus, parasitic organism, virus, not including chemical, pharmaceutical preparation or food; B) Lever, crowbar, hand tool without driving force;

C) Pliers, pincers, tongs - hand tool without driving force; D) Live animal; E) Work area or environment - the agent of the accident that occurred as a result of an atmospheric phenomenon, meteor, etc., as well as the action of solar radiation, should be included in this item; F) Box, crate, crate - packaging, container, empty or full; G) Floor - surface used to support people; H) Bottle, bottle - packaging, container, empty or full; I) Metal - includes ferrous and non-ferrous alloy, tube, plate, rail, rebar, wire, nut, rivet, nail, etc., includes molten metal, ingot, and foundry scrap, except ore; J) Motorcycle, scooter; K) Permanent walkway or platform - surface used to support people; L) Scaffolding floor and removable platform - surface used to support people; M) Vehicle floor surface used to support people; N) Street and road - surface used to support people; O) Alive Being; P) Scrap, rubble, waste; Q) Support surface - surface used to support people; R) Motorized road vehicle; S) Vehicle; T) Glassware, fiberglass, blade, except vial, bottle. 


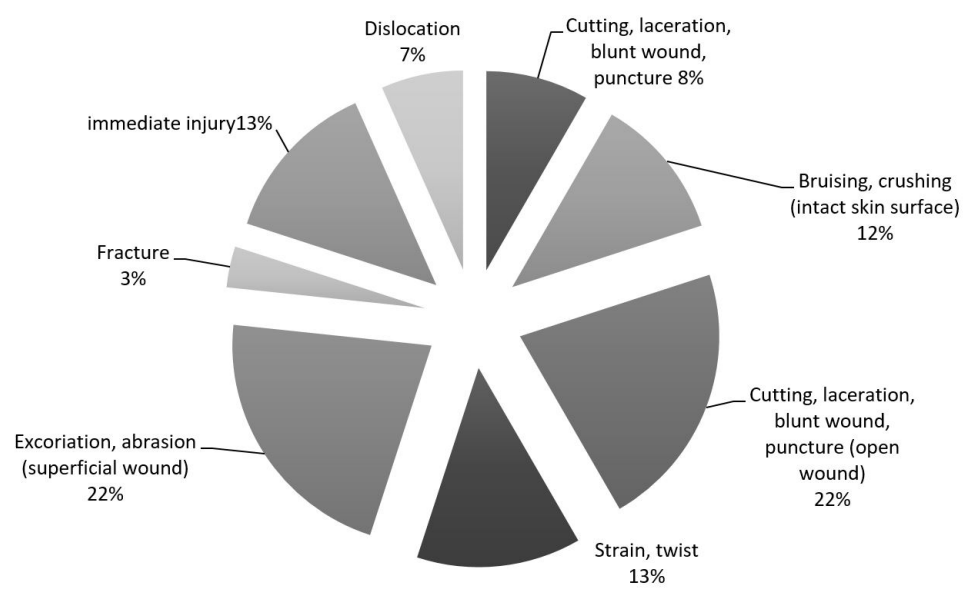

Figure 3. Nature of injuries at work accidents.

Table 7 presents the application of the RMT risk management tool for household solid waste collection services, through the relation between the environmental impacts raised by the Ad Hoc technique classified as negative and irreversible, and the accidents mapped in the research. In addition, ergonomic risks were included in the RMT, due to their importance and existence in any occupational activity.

Table 7. Application of the risk management tool (RMT) for household solid waste collection services.

\begin{tabular}{|c|c|c|c|c|c|}
\hline \multicolumn{6}{|c|}{ RMT - Home Solid Waste Collection Services } \\
\hline Risks & Causes & Consequences & Frequency & Severity & $\begin{array}{l}\text { Risk } \\
\text { Index }\end{array}$ \\
\hline Physicical & $\begin{array}{l}\text { Noise from the } \\
\text { collection trucks }\end{array}$ & $\begin{array}{l}\text { Worker: } \\
\text { discomfort } \\
\text { throughout the } \\
\text { workday }\end{array}$ & 5 & 1 & 5 \\
\hline Chemical & $\begin{array}{l}\text { Atmospheric } \\
\text { emissions }\end{array}$ & $\begin{array}{l}\text { Worker: } \\
\text { breathing } \\
\text { problems; } \\
\text { Environmental: } \\
\text { odor air } \\
\text { pollution }\end{array}$ & 5 & 1 & 5 \\
\hline Biological & $\begin{array}{l}\text { Contact with viruses, } \\
\text { fungi and bacteria } \\
\text { through poor } \\
\text { packaging of waste } \\
\text { and exposure to } \\
\text { loading and } \\
\text { unloading vehicles }\end{array}$ & $\begin{array}{l}\text { Worker: } \\
\text { occupational } \\
\text { diseases }\end{array}$ & 3 & 2 & 6 \\
\hline Accident & $\begin{array}{l}\text { Contact with sharps } \\
\text { due to poor } \\
\text { packaging }\end{array}$ & $\begin{array}{l}\text { Worker: Injuries } \\
\text { in general } \\
\text { Environmental: } \\
\text { contamination } \\
\text { of surface } \\
\text { water, } \\
\text { groundwater } \\
\text { and soil }\end{array}$ & 5 & 2 & 10 \\
\hline
\end{tabular}




\begin{tabular}{|c|c|c|c|c|c|}
\hline \multicolumn{6}{|c|}{ RMT - Home Solid Waste Collection Services } \\
\hline & $\begin{array}{l}\text { Holes and } \\
\text { pavements on streets } \\
\text { and roads }\end{array}$ & $\begin{array}{l}\text { Worker: } \\
\text { Dislocation, } \\
\text { distension, } \\
\text { twisting, } \\
\text { abrasions }\end{array}$ & 5 & 2 & 10 \\
\hline & Traffic & $\begin{array}{l}\text { Worker: } \\
\text { Fracture, } \\
\text { dislocation, } \\
\text { abrasions, } \\
\text { contusion, } \\
\text { crushing, } \\
\text { distension, } \\
\text { torsion }\end{array}$ & 4 & 4 & 12 \\
\hline & Loose animals & $\begin{array}{l}\text { Worker: cutting, } \\
\text { laceration, } \\
\text { injury, } \\
\text { abrasions }\end{array}$ & 4 & 2 & 8 \\
\hline Ergonomic & $\begin{array}{l}\text { Inadequate posture, } \\
\text { lifting and handling } \\
\text { bags with waste }\end{array}$ & $\begin{array}{l}\text { Worker: Body } \\
\text { aches }\end{array}$ & 5 & 1 & 5 \\
\hline
\end{tabular}

RMT explained how the risks of accidents are present in this area. The highest risk index (12), considered to be relevant, was for the cause "Traffic", which is a consequence of the attention and care of the population and the collection drivers themselves in vehicular driving, in addition to weather conditions and signaling and street infrastructure. Then, with the same risk index (10), considered as moderate, appear "Holes and Sidewalks in the Streets and Roads", a consequence attributed to the lack of investment in infrastructure in the municipalities and; o "Contact with Sharps Waste", which highlights the importance and the link between work accidents and the environment, as it generates negative consequences for both.

In order to reduce the risk index presented in Table 7, Tables 8 and 9 show the Action Plans and the application of $5 \mathrm{~W} 2 \mathrm{H}$, respectively, for the activity of collecting solid urban waste.

Table 8. Action plans.

\begin{tabular}{|c|c|c|}
\hline Risk Type & Causes & Action Plans \\
\hline \multirow[t]{4}{*}{ Tolerable } & \multirow[t]{2}{*}{ Noise from collection trucks } & $\begin{array}{l}\text { - Assess the noise levels to which workers } \\
\text { are exposed, installing a dosimeter on } \\
\text { workers and monitor the activities performed } \\
\text { by them, in order to verify that the sound } \\
\text { pressure is above } 85 \mathrm{~dB} \text { (A), following the NR- } \\
15 \text { (Brasil, 2014). }\end{array}$ \\
\hline & & $\begin{array}{l}\text { - Supply of personal protective equipment } \\
\text { (PPE) for hearing protection, such as hearing } \\
\text { protection insertion (Brasil, 2017). }\end{array}$ \\
\hline & \multirow[t]{2}{*}{ Atmosferic emissions } & $\begin{array}{l}\text { Atmospheric emissions - Requirement in bids } \\
\text { for trucks with recent years of manufacture, } \\
\text { which must have devices to control } \\
\text { atmospheric emissions. }\end{array}$ \\
\hline & & $\begin{array}{l}\text { - Provision of PPE for respiratory protection, } \\
\text { in case the employee feels discomfort, as a } \\
\text { semi facial filtering piece (PFF2) (Brasil, } \\
\text { 2017). }\end{array}$ \\
\hline
\end{tabular}


Table 8. Continued...

\begin{tabular}{|c|c|c|}
\hline Risk Type & Causes & Action Plans \\
\hline & \multirow{3}{*}{$\begin{array}{l}\text { Contact with viruses, fungi } \\
\text { and bacteria through poor } \\
\text { packaging of waste and } \\
\text { exposure to loading and } \\
\text { unloading vehicles }\end{array}$} & $\begin{array}{l}\text { - Supply of PPE for upper and lower limbs, } \\
\text { such as hand protection gloves and foot } \\
\text { protection shoes (Brasil, 2017). }\end{array}$ \\
\hline & & - Develop regular training for employees. \\
\hline & & $\begin{array}{l}\text { - Contact with citizens through awareness } \\
\text { campaigns regarding the management of } \\
\text { waste in homes. }\end{array}$ \\
\hline & \multirow{2}{*}{$\begin{array}{l}\text { Inadequate posture, lifting } \\
\text { and handling bags with } \\
\text { waste }\end{array}$} & - Develop regular training for employees. \\
\hline & & $\begin{array}{l}\text { - Provide workplace gymnastics classes } \\
\text { throughout the working day for employees } \\
\text { who remain at the corporate headquarters } \\
\text { and for those who arrive from the collection of } \\
\text { the streets. }\end{array}$ \\
\hline \multirow[t]{5}{*}{ Moderate } & \multirow[t]{3}{*}{$\begin{array}{l}\text { Contact with sharps } \\
\text { residues due to poor } \\
\text { packaging }\end{array}$} & $\begin{array}{l}\text { - Supply of PPE for upper and lower limbs, } \\
\text { such as gloves for hand protection and shoes } \\
\text { for foot protection (Brasil, 2017). }\end{array}$ \\
\hline & & - Develop regular training for employees. \\
\hline & & $\begin{array}{l}\text { - Contact with citizens through awareness } \\
\text { campaigns regarding the management of } \\
\text { waste in homes. }\end{array}$ \\
\hline & $\begin{array}{l}\text { Holes and sidewalks of } \\
\text { streets and roads }\end{array}$ & $\begin{array}{l}\text { - Forwarding of photographic reports to the } \\
\text { municipalities of the occurrences. }\end{array}$ \\
\hline & Loose animals & $\begin{array}{l}\text { - Contact with the residents of the affected } \\
\text { regions so that the animals in the } \\
\text { neighborhood remain leached for the best } \\
\text { performance of the services. }\end{array}$ \\
\hline Relevant & Traffic & Develop regular training for employees. \\
\hline
\end{tabular}

Table 9. Application of the 5W2H quality management tool.

\begin{tabular}{|c|c|c|c|c|c|c|c|}
\hline $\begin{array}{l}\text { Action Plan } \\
\text { selected }\end{array}$ & $\begin{array}{c}\text { "What" } \\
\text { What to do? }\end{array}$ & $\begin{array}{l}\text { "When" } \\
\text { When to } \\
\text { do it? }\end{array}$ & $\begin{array}{c}\text { "Who" Whos } \\
\text { is going to do } \\
\text { it? }\end{array}$ & $\begin{array}{c}\text { "Why" Why } \\
\text { do it? }\end{array}$ & $\begin{array}{c}\text { "Where" } \\
\text { Where to do } \\
\text { it? }\end{array}$ & $\begin{array}{l}\text { "How" How } \\
\text { to do it? }\end{array}$ & $\begin{array}{l}\text { "How Much" } \\
\text { How much } \\
\text { will it cost? }\end{array}$ \\
\hline $\begin{array}{l}\text { Assess the } \\
\text { noise levels } \\
\text { to which } \\
\text { workers are } \\
\text { exposed, } \\
\text { installing a } \\
\text { dosimeter on } \\
\text { the workers } \\
\text { and monitor } \\
\text { the activities } \\
\text { performed } \\
\text { by them, in } \\
\text { order to } \\
\text { verify that } \\
\text { the sound } \\
\text { pressure is } \\
\text { Tiable \&5dBon } \\
\text { (A), following } \\
\text { the NR-15 } \\
\text { (Brasil, } \\
\text { 2014). }\end{array}$ & $\begin{array}{l}\text { Measuring } \\
\text { ntinued... }\end{array}$ & $\begin{array}{l}\text { Throughou } \\
\text { t the } \\
\text { Workday }\end{array}$ & $\begin{array}{l}\text { Work Safety } \\
\text { Technician }\end{array}$ & $\begin{array}{l}\text { To assess } \\
\text { noise levels }\end{array}$ & $\begin{array}{l}\text { In all waste } \\
\text { collection } \\
\text { companies }\end{array}$ & $\begin{array}{l}\text { Install the } \\
\text { device } \\
\text { (calibrated) } \\
\text { on one of the } \\
\text { workers and } \\
\text { monitor the } \\
\text { measurement } \\
\text { throughout } \\
\text { the workday. }\end{array}$ & $\begin{array}{l}\mathrm{R} \$ 2,000.00 \\
\text { (purchase of } \\
\text { equipment) }\end{array}$ \\
\hline $\begin{array}{l}\text { Supply of } \\
\text { personal } \\
\text { protective } \\
\text { equipment } \\
\text { (PPE) for } \\
\text { hearing } \\
\text { protection, } \\
\text { such as } \\
\text { hearing }\end{array}$ & Provide PPE & Always & $\begin{array}{l}\text { Technical in } \\
\text { Occupational } \\
\text { Safety or } \\
\text { Operational } \\
\text { Supervisor }\end{array}$ & $\begin{array}{l}\text { To comply } \\
\text { with the } \\
\text { legislation } \\
\text { and take } \\
\text { care of the } \\
\text { health of } \\
\text { workers }\end{array}$ & $\begin{array}{l}\text { In all waste } \\
\text { collection } \\
\text { companies }\end{array}$ & $\begin{array}{l}\text { With the aid } \\
\text { of PPE } \\
\text { delivery } \\
\text { control sheets } \\
\text { per employee }\end{array}$ & $\begin{array}{l}\mathrm{R} \$ 285,00 \text { per } \\
\text { week in the } 7 \\
\text { municipalities }\end{array}$ \\
\hline
\end{tabular}




\begin{tabular}{|c|c|c|c|c|c|c|c|}
\hline $\begin{array}{l}\text { Action Plan } \\
\text { selected }\end{array}$ & $\begin{array}{c}\text { "What" } \\
\text { What to do? }\end{array}$ & $\begin{array}{l}\text { "When" } \\
\text { When to } \\
\text { do it? }\end{array}$ & $\begin{array}{c}\text { "Who" Whos } \\
\text { is going to do } \\
\text { it? }\end{array}$ & $\begin{array}{c}\text { "Why" Why } \\
\text { do it? }\end{array}$ & $\begin{array}{c}\text { "Where" } \\
\text { Where to do } \\
\text { it? }\end{array}$ & $\begin{array}{l}\text { “How” How } \\
\text { to do it? }\end{array}$ & $\begin{array}{l}\text { "How Much" } \\
\text { How much } \\
\text { will it cost? }\end{array}$ \\
\hline \multicolumn{8}{|l|}{$\begin{array}{l}\text { protection } \\
\text { insertion } \\
\text { (Brasil, } \\
2017 \text { ). }\end{array}$} \\
\hline $\begin{array}{l}\text { Requirement } \\
\text { in bids for } \\
\text { trucks with } \\
\text { recent years } \\
\text { of } \\
\text { manufacture } \\
\text {, which must } \\
\text { have } \\
\text { devices to } \\
\text { control } \\
\text { atmospheric } \\
\text { emissions. }\end{array}$ & $\begin{array}{l}\text { Use trucks } \\
\text { with a recent } \\
\text { manufacturin } \\
\text { g date }\end{array}$ & $\begin{array}{l}\text { When } \\
\text { required } \\
\text { by the bids }\end{array}$ & $\begin{array}{l}\text { Responsible } \\
\text { for preparing } \\
\text { the terms of } \\
\text { reference or } \\
\text { basic design } \\
\text { of the bids }\end{array}$ & $\begin{array}{l}\text { To reduce } \\
\text { atmospheric } \\
\text { emissions }\end{array}$ & $\begin{array}{l}\text { In all } \\
\text { municipalitie } \\
\text { s }\end{array}$ & $\begin{array}{l}\text { Hire qualified } \\
\text { people to } \\
\text { prepare bids } \\
\text { consistently } \\
\text { and carefully }\end{array}$ & Budget \\
\hline $\begin{array}{l}\text { Provision of } \\
\text { PPE for } \\
\text { respiratory } \\
\text { protection, in } \\
\text { case the } \\
\text { employee } \\
\text { feels } \\
\text { discomfort, } \\
\text { as a filtering } \\
\text { semi-facial } \\
\text { part (PFF2) } \\
\text { (Brasil, } \\
\text { 2017). }\end{array}$ & Provide PPE & Always & $\begin{array}{l}\text { Technical in } \\
\text { Workplace } \\
\text { Safety or } \\
\text { Operational } \\
\text { Supervisor }\end{array}$ & $\begin{array}{l}\text { To comply } \\
\text { with } \\
\text { legislation } \\
\text { and take } \\
\text { care of the } \\
\text { workers's } \\
\text { health. }\end{array}$ & $\begin{array}{l}\text { In all waste } \\
\text { collection } \\
\text { companies }\end{array}$ & $\begin{array}{l}\text { With the aid } \\
\text { of PPE } \\
\text { delivery } \\
\text { control sheets } \\
\text { per employee }\end{array}$ & $\begin{array}{l}\mathrm{R} \$ 266,00 \text { per } \\
\text { week in the } 7 \\
\text { municipalities }\end{array}$ \\
\hline $\begin{array}{l}\text { Provision of } \\
\text { PPE for } \\
\text { respiratory } \\
\text { protection, in } \\
\text { case the } \\
\text { employee } \\
\text { feels } \\
\text { discomfort, } \\
\text { as a filtering } \\
\text { semi-facial } \\
\text { part (PFF2) } \\
\text { (Brasil, } \\
\text { 2017). }\end{array}$ & Provide PPE & Always & $\begin{array}{l}\text { Technical in } \\
\text { Workplace } \\
\text { Safety or } \\
\text { Operational } \\
\text { Supervisor }\end{array}$ & $\begin{array}{l}\text { To comply } \\
\text { with the } \\
\text { legislation } \\
\text { and take } \\
\text { care of the } \\
\text { workers } \\
\text { 'health }\end{array}$ & $\begin{array}{l}\text { In all waste } \\
\text { collection } \\
\text { companies }\end{array}$ & $\begin{array}{l}\text { With the aid } \\
\text { of PPE } \\
\text { delivery } \\
\text { control sheets } \\
\text { per employee }\end{array}$ & $\begin{array}{l}\mathrm{R} \$ 1,045,00 \\
\text { per week in the } \\
7 \text { municipalities }\end{array}$ \\
\hline $\begin{array}{l}\text { Develop } \\
\text { regular } \\
\text { training for } \\
\text { employees. }\end{array}$ & $\begin{array}{l}\text { Train } \\
\text { employees }\end{array}$ & $\begin{array}{l}\text { Regularly, } \\
\text { following a } \\
\text { schedule } \\
\text { of activities }\end{array}$ & $\begin{array}{l}\text { Technical in } \\
\text { Workplace } \\
\text { Safety }\end{array}$ & $\begin{array}{l}\text { So that } \\
\text { workers are } \\
\text { aware of the } \\
\text { risks to } \\
\text { which they } \\
\text { are exposed } \\
\text { and the } \\
\text { importance } \\
\text { of the proper } \\
\text { use of PPE }\end{array}$ & $\begin{array}{l}\text { At company } \\
\text { headquarter } \\
\mathrm{s}\end{array}$ & $\begin{array}{l}\text { Through } \\
\text { lectures and } \\
\text { routine } \\
\text { conversations } \\
\text {, with visual } \\
\text { presentation } \\
\text { and delivery } \\
\text { of printed } \\
\text { material }\end{array}$ & $\begin{array}{l}\text { Travel, } \\
\text { accommodatio } \\
\mathrm{n} \text { and food for } \\
\text { the Safety } \\
\text { technician - R } \$ \\
350.00 \text { for } \\
\text { each } \\
\text { municipality to } \\
\text { be served }\end{array}$ \\
\hline $\begin{array}{l}\text { Contact with } \\
\text { citizens } \\
\text { through } \\
\text { awareness } \\
\text { campaigns } \\
\text { regarding } \\
\text { the } \\
\text { managemen } \\
\text { t of residues } \\
\text { in homes. }\end{array}$ & $\begin{array}{l}\text { Get in touch } \\
\text { with citizens }\end{array}$ & $\begin{array}{l}\text { Regularly, } \\
\text { following a } \\
\text { schedule } \\
\text { of activities }\end{array}$ & $\begin{array}{l}\text { Operational } \\
\text { and } \\
\text { Administrative } \\
\text { Assistant }\end{array}$ & $\begin{array}{l}\text { In order to } \\
\text { raise } \\
\text { awareness } \\
\text { of the } \\
\text { population } \\
\text { on the } \\
\text { correct } \\
\text { managemen } \\
\text { t of waste }\end{array}$ & $\begin{array}{l}\text { In all } \\
\text { municipalitie } \\
\text { s }\end{array}$ & $\begin{array}{l}\text { Lectures at } \\
\text { schools and } \\
\text { delivery of } \\
\text { printed } \\
\text { material at } \\
\text { strategic } \\
\text { points }\end{array}$ & $\begin{array}{l}\mathrm{R} \$ 1,000.00- \\
\text { Folders }\end{array}$ \\
\hline
\end{tabular}


Table 9. Continued...

\begin{tabular}{|c|c|c|c|c|c|c|c|}
\hline $\begin{array}{l}\text { Action Plan } \\
\text { selected }\end{array}$ & $\begin{array}{c}\text { "What" } \\
\text { What to do? }\end{array}$ & $\begin{array}{c}\text { "When" } \\
\text { When to } \\
\text { do it? }\end{array}$ & $\begin{array}{c}\text { "Who" Whos } \\
\text { is going to do } \\
\text { it? }\end{array}$ & $\begin{array}{c}\text { "Why" Why } \\
\text { do it? }\end{array}$ & $\begin{array}{l}\text { "Where" } \\
\text { Where to do } \\
\text { it? }\end{array}$ & $\begin{array}{l}\text { "How" How } \\
\text { to do it? }\end{array}$ & $\begin{array}{l}\text { "How Much" } \\
\text { How much } \\
\text { will it cost? }\end{array}$ \\
\hline $\begin{array}{l}\text { Provide } \\
\text { workplace } \\
\text { gymnastics } \\
\text { classes } \\
\text { throughout } \\
\text { the working } \\
\text { day for } \\
\text { employees } \\
\text { who remain } \\
\text { at the } \\
\text { corporate } \\
\text { headquarter } \\
\text { s and for } \\
\text { those who } \\
\text { arrive from } \\
\text { the } \\
\text { collection of } \\
\text { the streets }\end{array}$ & $\begin{array}{l}\text { Occupational } \\
\text { gymnastics } \\
\text { classes }\end{array}$ & $\begin{array}{l}\text { Regularly, } \\
\text { following a } \\
\text { schedule } \\
\text { of activities }\end{array}$ & $\begin{array}{l}\text { Physical } \\
\text { Educator or } \\
\text { Physiotherapis } \\
\text { t }\end{array}$ & $\begin{array}{l}\text { Taking care } \\
\text { of the } \\
\text { ergonomic } \\
\text { risks to } \\
\text { which } \\
\text { workers are } \\
\text { exposed }\end{array}$ & $\begin{array}{l}\text { At company } \\
\text { headquarter } \\
\mathrm{s}\end{array}$ & $\begin{array}{l}\text { With available } \\
\text { hours for the } \\
\text { activity }\end{array}$ & $\begin{array}{l}\mathrm{R} \$ 200.00 \text { per } \\
\text { hour }\end{array}$ \\
\hline $\begin{array}{l}\text { Forwarding } \\
\text { of } \\
\text { photographic } \\
\text { reports to } \\
\text { the } \\
\text { municipalitie } \\
\text { s of the } \\
\text { occurrences }\end{array}$ & $\begin{array}{l}\text { Delivery of } \\
\text { reports }\end{array}$ & Monthly & $\begin{array}{l}\text { Administrative } \\
\text { Assistant }\end{array}$ & $\begin{array}{l}\text { To report on } \\
\text { the } \\
\text { infrastructur } \\
\text { e situation of } \\
\text { municipalitie } \\
\mathrm{s}\end{array}$ & In city halls & $\begin{array}{l}\text { Delivering in } \\
\text { print (with } \\
\text { protocol) and } \\
\text { via internet }\end{array}$ & $\begin{array}{l}\text { No costs for } \\
\text { city halls }\end{array}$ \\
\hline
\end{tabular}

\section{Conclusions}

The practices of inadequate management of the generated urban solid waste cause environmental impacts, health problems and public safety. Therefore, this article aimed to combine environmental and work safety concepts through a survey in 7 (seven) municipalities in the state of Rio Grande do Sul around the collection of solid urban waste services with the objective of instructing companies in this area to use tools raise information on environmental impacts, risk management and quality management to perform a more professionalized management of the actions performed by its employees.

The application of the Ad Hoc methodology for the assessment of environmental impacts resulted in pointing out the environmental aspects of surface waters, groundwater, soil, fauna and flora as causing environmental impacts with negative, problematic, long-term and irreversible effects. On the other hand, the aspects of infrastructure, socioeconomic aspects and compatibility with municipal plans were characterized as causing social impacts with positive, beneficial, long-term and reversible effects, due to the dependence on the variation of public management.

Analyzes of work accidents, which occurred in 2017, showed that all 60 work accidents recorded occurred with urban waste collectors and that in 51 of the cases injuries occurred with lost time. The average percentage of employees who suffered accidents at work was $37.50 \%$. The accidents that had as causative agents "glassware, fiberglass, blade, except vial, bottle" were the most frequent, with 13 events, followed by "street and road - surface used to support people" with 10 occurrences.

The most common types of injuries were "excoriation and abrasion (superficial wound)" and "cut, laceration, blunt wound, puncture (open wound)", both with $22 \%$, followed by "immediate injury", and "distention and twist" with $13 \%$. It was concluded, therefore, that in this field the collectors suffer many accidents at work, with serious injuries that lead to removal from activity. 
With the application of the RMT risk management tool, each type of risk (physical, chemical, biological, accident and ergonomic) was associated with causes and their respective consequences, for the worker and for the environment, and then an index risk was calculated. The highest risk index, classified as relevant, is caused by the risk of accidents with the cause "Traffic", which is dependent on the responsibility, attention and care of the population and the collection driver himself in vehicular driving, in addition to climatic conditions and street signs and infrastructure. In the sequence of importance, with the moderate risk index, there are still risks of accidents, however caused by "Contact with sharps due to poor packaging" and "Holes and pavements in the streets and roads". The first with consequences for both the worker and negative impacts on the environment, and the second with consequences only for the worker.

To minimize the risks of accidents at work and the environmental impacts pointed out, the Action Plans present some suggestions such as the provision of adequate PPE for services, the development of regular training, the provision of work gymnastics for employees, contact with employees, citizens and others. As a complement, the 5W2H quality management tool showed how Action Plans can be implemented, detailing "what should be done", "when to be done", "who is going to do it", "why do it", "where to do it", "how to do it" and "how much it will cost".

Therefore, this article showed that it is possible to improve the management of the activities of a company in the area of urban solid waste collection, combining multidisciplinarity between the environmental part and that of work safety. It is suggested that further studies on this theme are carried out with other types of waste, as well as with different branches of services, industries and others.

\section{References}

Aleluia, J., \& Ferrão, P. (2016). Characterization of urban waste management practices in developing Asian countries: a new analytical framework based on waste characteristics and urban dimension. Waste Management (New York, N.Y.), 58, 415-429. http://dx.doi.org/10.1016/j.wasman.2016.05.008. PMid:27220609.

Associação Brasileira de Empresas de Limpeza Pública e Resíduos Especiais - ABRELPE. (2016). Panorama dos resíduos sólidos no Brasil. São Paulo: ABRELPE.

Associação Brasileira de Normas Técnicas - ABNT. (2001). ABNT NBR:14.280: Cadastro de acidente do trabalho - Procedimento e classificação. Rio de Janeiro: ABNT.

Associação Brasileira de Normas Técnicas - ABNT. (2012). ABNT NBR ISO/IEC 31010 : Gestão de riscos - Técnicas para o processo de avaliação de riscos. Rio de Janeiro: ABNT.

Associação Brasileira de Normas Técnicas - ABNT. (2015). ABNT NBR ISO NBR 9001: Sistemas de gestão de qualidade - Requisitos. Rio de Janeiro: ABNT.

Bernstad Saraiva, A., Souza, R. G., \& Valle, R. A. B. (2017). Comparative lifecycle assessment of alternatives for waste management in Rio de Janeiro - Investigating the influence of an attributional or consequential approach. Waste Management (New York, N.Y.), 68(Suppl C), 701-710. http://dx.doi.org/10.1016/j.wasman.2017.07.002. PMid:28712597.

Brasil. (2010). Lei $n^{\circ}$ 12.305, de 2 de Agosto de 2010. Institui a Política Nacional de Resíduos Sólidos; altera a Lei $n^{\circ}$ 9.605, de 12 de fevereiro de 1998; e dá outras providências. Brasília, DF: Diário Oficial da República Federativa do Brasil.

Brasil. (2014). NR 15 - Atividades e Operações Insalubres. Brasília, DF: Diário Oficial da República Federativa do Brasil. 
Brasil. (2016). NR 4 - Serviços Especializados em Engenharia de Segurança e em Medicina do Trabalho - SESMT. Brasília: Secretaria Especial de Previdência e Trabalho.

Brasil. (2017). NR 6 - Equipamentos de Proteção Individual - EPI. Brasília, DF: Diário Oficial da República Federativa do Brasil.

Carra, S. H. Z., \& Reichert, G. A. (2014). Avaliação do ciclo de vida de resíduos sólidos urbanos: avaliação de dois cenários para o gerenciamento integrado de resíduos sólidos na cidade de Porto Alegre/RS. In Anais do $4^{\circ}$ Congresso Internacional de Tecnologias para o Meio Ambiente. Bento Gonçalves: Universidade de Caxias do Sul.

Comberti, L., Demichela, M., \& Baldissone, G. (2018). A combined approach for the analysis of large occupational accident databases to support accident-prevention decision making. Safety Science, 106, 191-202. http://dx.doi.org/10.1016/j.ssci.2018.03.014.

Cremonez, F. E., Cremonez, P. A., Feroldi, M., Camargo, M. P., Klajn, F. F., \& Feiden, A. (2014). Avaliação de impacto ambiental: metodologias aplicadas no Brasil. Revista Monografias Ambientais, 13(5), 3821-3830. http://dx.doi.org/10.5902/2236130814689.

Da Silva, T. C. F., Santos, M. B. G., Cocalo, S. A., Rangel, M. H., \& Da Cunha, J. C. M. (2017). Análise preliminar de riscos em uma indústria metalúrgica. In Anais do XXXVII Encontro Nacional de Engenharia de Produção. Rio de Janeiro: ABEPRO.

De Cicco, F., \& Fantazzini, M. L. (2003). Tecnologias consagradas de gestão de riscos. São Paulo: Risk Tecnologia Editora Ltda.

de Jesus Galdino, S., \& Malysz, S. T. (2016). Os riscos ocupacionais dos garis coletores de resíduos sólidos urbanos. Revista Percurso, 8(2), 187-205.

Deus, R. M., Battistelle, R. A. G., \& Silva, G. H. R. (2017). Current and future environmental impact of household solid waste management scenarios for a region of Brazil: carbon dioxide and energy analysis. Journal of Cleaner Production, 155(Pt 1), 218-228. http://dx.doi.org/10.1016/j.jclepro.2016.05.158.

Di Maria, F., Micale, C., \& Morettini, E. (2016). Impact of the pre-collection phase at different intensities of source segregation of bio-waste: an Italian case study. Waste Management (New York, N.Y.), 53, 12-21. http://dx.doi.org/10.1016/j.wasman.2016.04.026. PMid:27157709.

Empresa de Tecnologia e Informações da Previdência Social - DATAPREV. (2016). AEAT InfoLogo: Base de dados históricos de acidentes de trabalho. Brasília: DATAPREV.

Empresa de Tecnologia e Informações da Previdência Social - DATAPREV. (2018). AEAT Infologo - base de dados históricos de acidentes de trabalho: estatísticas de acidentes do trabalho. Retrieved in 2018, May 22, from http://www3.dataprev.gov.br/aeat/

Erses Yay, A. S. (2015). Application of life cycle assessment (LCA) for municipal solid waste management: a case study of Sakarya. Journal of Cleaner Production, 94, 284-293. http://dx.doi.org/10.1016/j.jclepro.2015.01.089.

Faria, M. T. (2011). Ferramentas de gestão de riscos. Curitiba: UTFPR. Apostila preparada para o Curso de Engenharia de Segurança do Trabalho.

Herva, M., Neto, B., \& Roca, E. (2014). Environmental assessment of the integrated municipal solid waste management system in Porto (Portugal). Journal of Cleaner Production, 70, 183-193. http://dx.doi.org/10.1016/j.jclepro.2014.02.007.

Nunhes, T. V., Motta Barbosa, L. C. F., \& de Oliveira, O. J. (2017). Identification and analysis of the elements and functions integrable in integrated management systems. Journal of Cleaner Production, 142, 3225-3235. http://dx.doi.org/10.1016/j.jclepro.2016.10.147.

Reichert, G. A., \& Mendes, C. A. B. (2014). Avaliação do ciclo de vida e apoio à decisão em gerenciamento integrado e sustentável de resíduos sólidos urbanos. Engenharia Sanitaria e Ambiental, 19(3), 301-313. http://dx.doi.org/10.1590/S1413-41522014019000001145.

Ripa, M., Fiorentino, G., Vacca, V., \& Ulgiati, S. (2017). The relevance of site-specific data in Life Cycle Assessment (LCA). The case of the municipal solid waste management in the 
metropolitan city of Naples (Italy). Journal of Cleaner Production, 142, 445-460.

http://dx.doi.org/10.1016/j.jclepro.2016.09.149.

Silva, F. F. D., Nagalli, A., Dandolin, C. S. L., \& Catai, R. E. (2016). Análise de riscos dos trabalhadores da coleta de resíduos sólidos urbanos. In Anais do XXVI Encontro Nacional de Engenharia de Produção. Rio de Janeiro: ABEPRO.

Stamm, H. R. (2003). Método para avaliação de impacto ambiental (AIA) em projetos de grande porte: Estudo de caso de uma usina termelétrica (Tese de doutorado). Programa de Pós-graduação em Engenharia de Produção, Universidade Federal de Santa Catarina, Florianópolis.

Struk, M. (2017). Distance and incentives matter: the separation of recyclable municipal waste. Resources, Conservation and Recycling, 122, 155-162. http://dx.doi.org/10.1016/j.resconrec.2017.01.023.

Sukholthaman, P., \& Sharp, A. (2016). A system dynamics model to evaluate effects of source separation of municipal solid waste management: A case of Bangkok, Thailand. Waste Management (New York, N.Y.), 52, 50-61. http://dx.doi.org/10.1016/j.wasman.2016.03.026. PMid:27026497. 